\title{
Regulatory issues surrounding the temporary authorisation of animal vaccination in emergency situations: the example of bluetongue in Europe
}

\author{
C. Saegerman (1), M. Hubaux (2), B. Urbain (3), L. Lengelé (2) \& D. Berkvens (4) \\ (1) Department of Infectious and Parasitic Diseases, Epidemiology and Risk Analysis Applied to Veterinary \\ Sciences, Faculty of Veterinary Medicine, University of Liège, Boulevard de Colonster, 20, B42, B-4000 Liège, \\ Belgium \\ (2) Directorate-General for Animals, Plants and Foodstuffs, Federal Public Service of Public Health, Food \\ Chain Safety and Environment, Eurostation II - 7th floor, Place Victor Horta 40 box 10, B-1060 Brussels, \\ Belgium \\ (3) Marketing Authorisation Veterinary Unit, Federal Agency for Medicinal and Health Products, Eurostation II \\ - 8th floor, Place Victor Horta 40 box 40, B-1060 Brussels, Belgium \\ (4) Department of Animal Health, Unit of Epidemiology and Applied Statistics, Prince Leopold Institute of \\ Tropical Medicine, Nationalestraat 155, B-2000 Antwerp, Belgium
}

\section{Summary}

A marketing authorisation for a veterinary vaccine is granted after the quality, safety and efficacy of the product have been assessed in accordance with legal standards. The assessment includes complete characterisation and identification of seed material and ingredients, laboratory and host animal safety and efficacy studies, stability studies, and post-licensing monitoring of field performance. This assessment may not be possible during the emergence of a new animal disease, but several mechanisms exist to allow for the availability of products in an emergency animal health situation, e.g. autogenous biologics, conditional licences, experimental and emergency use authorisations, the importation of products in use elsewhere in the world and pre-approved vaccine banks. Using the emergence of bluetongue in northern Europe as an example, the regulatory issues regarding the temporary authorisation of animal vaccination are described. Several conditions must be fulfilled before a temporary authorisation can be granted, e.g. inactivated vaccines should be used in order to exclude reversion to virulence and reassortment between vaccine viruses and/or field strains of the bluetongue virus; decision-making must be supported by scientific evidence and risk analysis; there must be a complete census of the susceptible animals that were vaccinated; vaccination protocols must be adhered to and there must be a scheme allowing for registration, delivery and follow-up of vaccination, and monitoring, analysis and, possibly, adjustment of field use of the vaccination. This temporary authorisation must be replaced by a full authorisation as quickly as possible.

\section{Keywords}

Animal health - Emerging disease - Regulatory issues - Temporary authorisation Vaccination - Vaccine. 


\section{Introduction}

Each and every animal disease control and/or eradication programme is based on two general principles:

a) the control of infected herds through the application of corrective control measures

b) the protection of infection-free herds through preventive measures.

The identification of individual animals and herd registers are two essential prerequisites before these principles can be applied. The herd is the epidemiological unit of interest in disease control programmes.

The above indicates that different strategic options can be adopted, separately or conjointly, firstly to decrease the prevalence to an acceptable level (disease control) and secondly to eliminate the remaining clinical or sub-clinical infection foci (disease eradication). The overall strategy consists of one or more of the following steps:

a) generalised compulsory vaccination of the entire susceptible population (medical prophylaxis);

b) slaughter of known infected animals (test and slaughter) combined with a selective vaccination programme, including either only the subclass of animals at risk (e.g. young naive animals) or all animals in a limited area depending on the prevalence (medico-sanitary prophylaxis)

c) stamping out of animals known to be infected or exposed (sanitary prophylaxis). Adequate compensation for the animals slaughtered is an unavoidable requirement for success of the programme (86).

The choice of the different steps to be undertaken depends on a certain number of considerations, amongst them:

- infection prevalence in the different susceptible animal species (and human clinical incidence in the case of a zoonosis)

- the structure and management of the livestock sector

- the availability of a national reference laboratory and regional laboratories

- the capacity of the Veterinary Services to follow up the programme and to control livestock movements and the cooperation between the Veterinary Services and the private sector in the implementation of such a programme

- the involvement of political decision-makers and their willingness to support an uninterrupted effort over many years, sometimes several decades

- the availability of financial resources and the capacity to mobilise extra funds

- the coordination and collaboration between the Health and Agriculture Ministries when planning the programme
- the level of involvement of farmers organisations, which ideally should be convinced of the benefits of the exercise before the start of the programme $(5,86)$.

Each party concerned must participate in developing and implementing disease control programmes, in financing these programmes and in taking responsibility for their implementation, and each party must be rewarded for their achievements. This is the principle of joint decisionmaking, joint financing and joint accountability (44).

A prerequisite for any programme is the implementation of an efficient animal disease surveillance network, capable of monitoring the progress made, and being able to adjust the strategy when required (55). Every programme must therefore be evaluated regularly and performance indicators must be set beforehand (87). Moreover, the strategy must be adjusted not only according to the epidemiological situation, but also in the light of new scientific knowledge (86).

In the case of countries that are free of a disease vaccination is usually not practised, but the option to use vaccination in an emerging disease situation is still available (101). Moreover, policies involving mass slaughtering being less and less popular, there is a tendency to use so-called marker vaccines together with a companion diagnostic test $(33,76)$.

A marketing authorisation for a veterinary vaccine is granted after the quality, safety and efficacy of the product have been assessed in accordance with legal standards (18, 22, 48). Even when using an accelerated assessment procedure it can still take a long time before authorisation is granted. However, Member States are authorised to use vaccines without a marketing authorisation in an emergency situation. Using the example of the emergence of bluetongue (BT) in Europe, the advantages and disadvantages of this temporary authorisation permit are discussed and solutions to improve this unusual situation are proposed.

\section{Emergency situations}

Several definitions of an emerging disease coexist (9, 13, 69,77 ) but they all have a common denominator. An emerging disease is a disease of which the true incidence increases in a significant way in a given population, in a given area and during a given period, in comparison with the usual epidemiological situation of this disease (103). This increase in true incidence is due to several factors, such as the evolution or the modification of a pathogenic agent or an existing parasite, which results in a change of host, of vector, of pathogenicity or strain $(68,116)$. Specific social, ecological, climatic, environmental and 
demographic factors precipitate the emergence of a disease $(69,97,113,114)$, but it is difficult to establish a ranking of causes or of mechanisms (81).

There are several models for understanding emerging risks, they include:

a) the convergence model for zoonotic diseases (53)

b) the pan European pro-active identification of emerging risks in the field of food production model (PERIAPT) concerning emerging risk in the food chain (108)

c) the generalised model for rare events $(85,87)$.

The example of the recent BT epidemic in northern Europe is treated more in detail hereafter $(24,43,102,104)$.

Bluetongue virus (BTV) is the prototype species of the genus Orbivirus in the family Reoviridae. The viral genome consists of 10 double-stranded RNA segments that encode for four non-structural (NS1, NS2, NS3 and NS3A) and seven structural (VP1-VP7) proteins $(82,111)$. Currently, there are 24 known serotypes of BTV worldwide (63). However, a genetic diversity of BTV exists and it is a consequence of both drift (i.e. point mutations) and shift (i.e. reassortment of individual BTV gene segments). Serotypes 1, 2, 3, 4, 6 and 10 are known to have a high pathogenic index and high epidemic potential (18). Bluetongue is a notifiable disease of the World Organisation for Animal Health (OIE), and is thus of serious socio-economic concern and of major importance in the international trade of animals and animal products (18). The BTV is transmitted between its ruminant hosts exclusively by bites of Culicoides midges (60, 61). Transmission is limited to seasons during which adult insects are active. Bluetongue is thought to infect all known ruminant species. However, severe disease usually occurs only in certain breeds of sheep and in some species of deer $(57,74,100)$. Both cattle and goats suffer from unapparent infection, but probably serve as important reservoirs of the virus for sheep and wild ruminants (57, 109). Common clinical signs include fever, salivation, abundant nasal discharge, oedema (particularly in the head region), congestion, ulcerations of the oral mucosa, lameness, depression and, sometimes, cyanosis of the tongue $(45,57)$. The mortality rate and the severity of the clinical signs seem to be dependant on factors such as the breed and age of the animal infected (older age groups being more susceptible) and the type and strain of the virus (62). Because BTV infection is not contagious, meat and dairy products pose no hazard for the spread of the pathogen in ruminants. However, blood and other biologicals for cell culture or in vivo use are a potential risk for spread $(20,118)$.

The genus Culicoides comprises 1,260 species, of which 30, to a greater or lesser extent, are involved in the transmission of orbiviral diseases injurious to livestock almost worldwide. Until recently, Culicoides imicola (Kieffer) was believed to be the only vector of BTV in both Africa and southern Europe (43), but it is now known that other newly identified (and as yet unidentified) vectors are involved. Other possible factors that have contributed to the spread of BTV include animal migration and importation, extension in the distribution of its major vector, Culicoides spp., the apparent ability of the virus to overwinter in the absence of adult vectors, and its occurrence in healthy reservoir hosts, such as cattle and some wild ruminants $(18,79,99)$.

In 2004, bluetongue was reported in nine countries in the world (115) (Fig. 1). Between 1998 and 2004, when there were incursions of BTV into the Mediterranean Basin, the Balkans and beyond (Table I), the disease penetrated into areas where $C$. imicola does not occur, thus incriminating novel vectors $(3,8,12,42,62,64,119)$. This was confirmed subsequently when the causative virus was isolated from mixed pools of the two species Culicoides obsoletus (Meigen) and Culicoides scoticus (Downes and Kettle) collected in central Italy $(92,93)$ and from Culicoides pulicaris (Linnaeus) in Sicily (11).

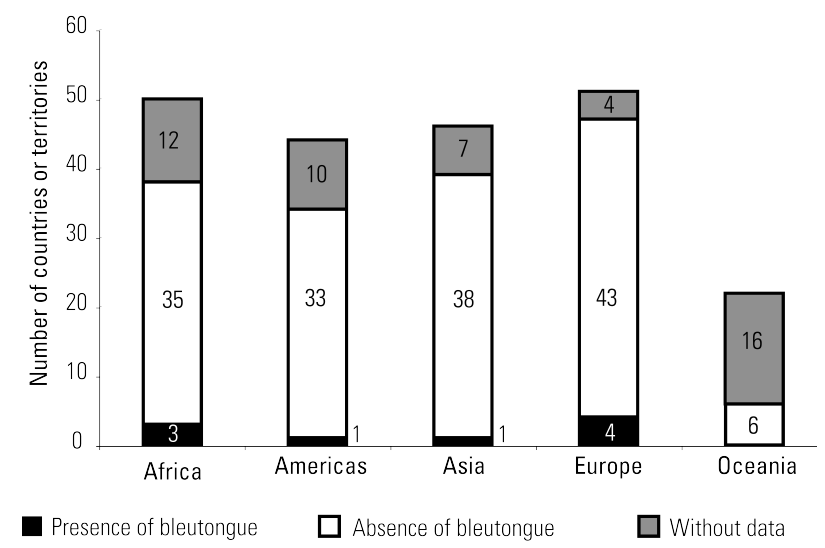

Fig. 1

Bluetongue throughout the world in 2004

Source: Handistatus II (http://www.oie.int/hs2/report.asp?lang=en) (115)

Bluetongue appeared for the first time in the north of Europe (Fig. 2) following a heat wave and strong rains, and can be defined as being an emergent disease in this zone (116). After the first notification on 17 August 2006 (19), more than 1,200 cases of BT were entered in the European Commission's Animal Disease Notification System (http://ec.europa.eu/food/animal/diseases/adns/index_en. htm). In this area, BTV was isolated from Culicoides dewulfi (Goetghebuer) (58), an indigenous European Culicoides species (Fig. 3) - thereby increasing the risk of transmission over larger geographical regions $(42,79)$. 
Table I

Outbreaks of bluetongue in Europe in the period 1998-2004

$(7,62,75,115)$

\begin{tabular}{|c|c|c|c|}
\hline Country & Year of first outbreak & Serotype(s) of bluetongue virus & Main vector(s) identified \\
\hline Albania & 2002 & 9 & Culicoides obsoletus, C. pulicaris \\
\hline Bosnia-Herzegovina & 2002 & 9 & ND \\
\hline Bulgaria & 1999 & 9 & C. obsoletus, C. pulicaris \\
\hline Croatia & 2001 & 9,16 & C. obsoletus, C. scoticus \\
\hline Cyprus & 2003 & 16 & C. obsoletus, C. pulicaris \\
\hline Former Yugoslav Republic of Macedonia & 2001 & 9 & ND \\
\hline France (Corsica) & 2000 & 2 & C. imicola, C. pulicaris, C. obsoletus \\
\hline Greece & 1998 & $1,4,9,16$ & C. imicola, C. obsoletus \\
\hline Italy & & $2,9,16$ & C. imicola, C. obsoletus, C. pulicaris \\
\hline Kosovo & 2001 & 9 & ND \\
\hline Portugal & 2004 & $N D^{(a)}$ & C. imicola, C. obsoletus, C. pulicaris \\
\hline Serbia and Montenegro & 2001 & 9 & ND \\
\hline Spain & 2000 & 2 & C. imicola, C. obsoletus, C. pulicaris \\
\hline Turkey & 1999 & 9,16 & C. imicola \\
\hline
\end{tabular}

ND: no data recorded

a) Probably serotype 4

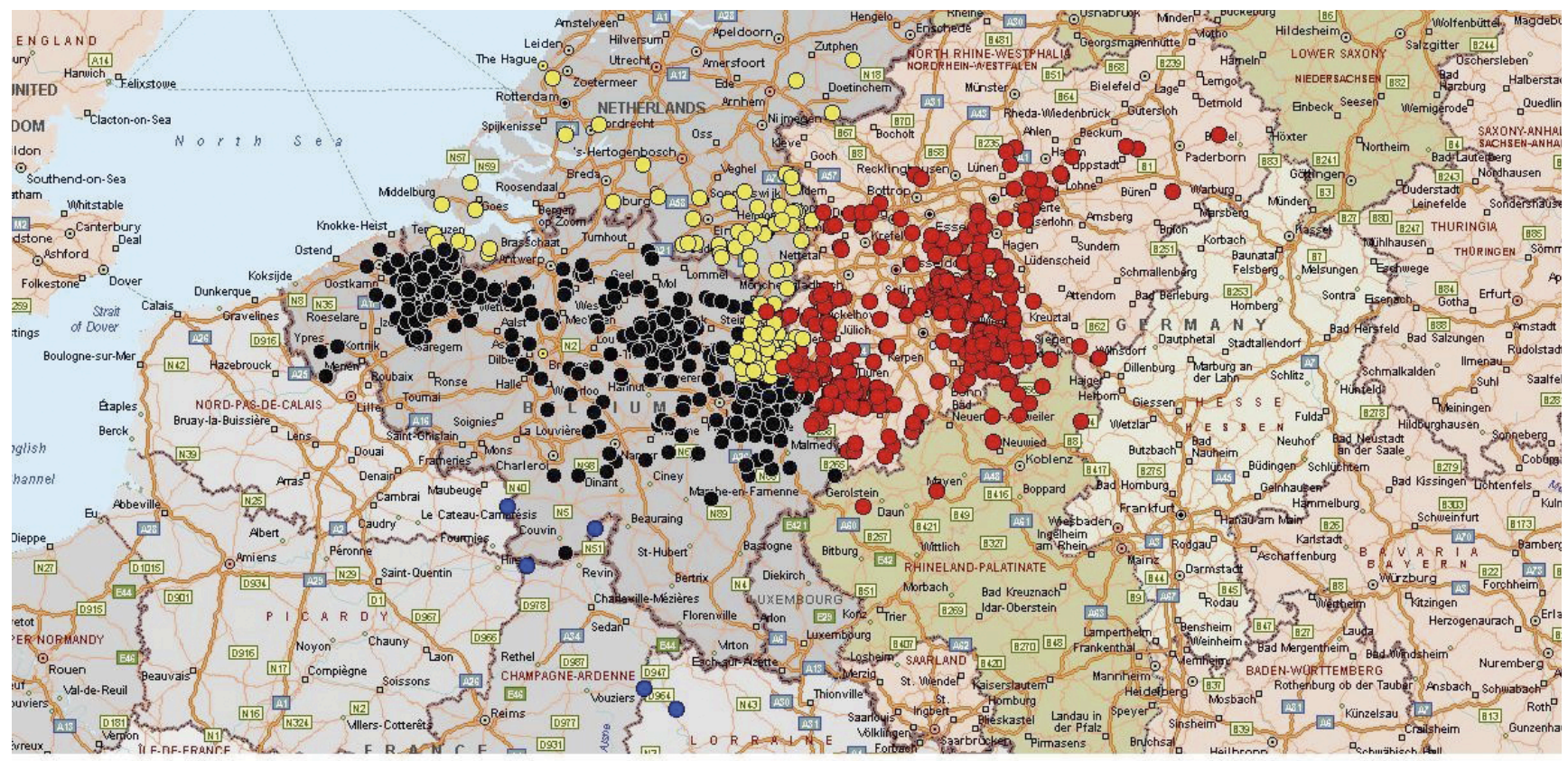

Black circle (Belgium; $n=460$ )

Red circle (Germany: $n=457$ )

Yellow circle (Netherlands; $n=306$ )

Blue circle (France; $n=5$ )

Fig. 2

Bluetongue outbreaks (serotype 8) in northern Europe between 17 August and 25 October 2006

Source: European Commission's Animal Disease Notification System, 2006 


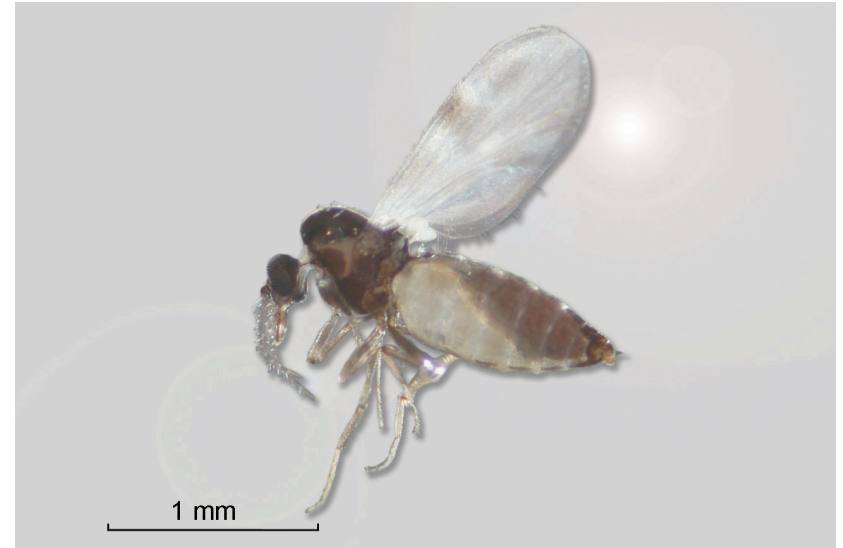

Fig. 3

Gravid female of Culicoides dewulfi isolated near outbreaks in Belgium in 2006

(Reginald De Deken and Maxime Madder, Institute of Tropical Medicine, Antwerpen, Belgium)

This recent finding is an important new epidemiological event, because previously most BT outbreaks were linked to C. imicola. Culicoides dewulfi has been reported throughout the Palaearctic area $(52,105)$. This indicates that the disease could now remain in the rest of Europe where cattle and horses are kept (C. dewulfi is known to breed in cattle dung and horse dung), with the risk of more cases of orbiviral diseases such as BT occurring during the following spring when the vector activity is high (58).

The global distribution of the BTV endemic areas has traditionally been accepted to be between the latitudes of approximately $50^{\circ} \mathrm{N}$ and $35^{\circ} \mathrm{S}(17,54,61,80)$. There is now enough scientific evidence to show that it has spread further north, to $53^{\circ} \mathrm{N}(58,117)$.

\section{Vaccination as a strategic option}

Strategies for controlling BT range from control measures in areas free from the disease to systematic vaccination in BT endemic areas. In areas free from BT but where Culicoides spp. are present, any introduction of live animals from infected countries should be controlled bearing in mind the maximum duration of viraemia (e.g. quarantine for at least 60 days is recommended by the OIE). When importing ruminant semen or embryos/ova from suspected infected areas, donors are kept in quarantine and protected from potential vectors for at least 60 days prior to collection, or donors are tested according to the protocol outlined in the OIE Terrestrial Animal Health Code (118). In recently infected areas, eradication of BTV is theoretically possible by adopting a range of methods, including some or all of the following:

- animal movement restrictions

- serological/virological surveys and slaughtering of infected and potentially infected animals

- vaccination and/or vector control (e.g. use of insecticide or keeping animals indoor during periods of high vector activity) (Table II).

In areas where BTV is enzootic, controlling the vectors is usually considered to be impossible and any reduction in their numbers is transient (56). Nevertheless, attempts to control vector populations have been implemented using chemical repellents and/or insecticide treatment $(6,91,98$, 112).

With regard to prophylaxis, possibly the best way to control clinical BT outbreaks in endemic areas is to

\section{Table II}

Control, safeguard and preventive measures against bluetongue applied in Eastern Europe, 1998-2004 (adapted from 62, 75)

\begin{tabular}{ll}
\hline Control measures & Safeguard measures \\
\hline Modified stamping out policy, i.e. killing and destroying clinically & Protection zone \\
affected animals (viraemic animals) to prevent them acting as a & Surveillance zone \\
source of virus for vector insects & Restricting the movement of animals and germinal \\
Vector control measures by means of insecticides and/or insect & products to prevent new foci or infection \\
repellents & \\
Intensive clinical surveillance & \\
Serological surveillance & \\
Virological surveillance & \\
Entomological surveillance &
\end{tabular}




\section{Table III}

Available bluetongue vaccines

(according to $15,18,34,94,119$ )

\begin{tabular}{|c|c|c|c|c|}
\hline Type (form) & Species & Valences & Strains & Producer \\
\hline \multirow[t]{5}{*}{ Inactivated (suspension) } & Sheep ${ }^{(a)}$ & Monovalent & $2 \& 4$ & Mérial SAS, Lyons, France \\
\hline & & Polyvalent & $16 \& 9$ in development & \\
\hline & Sheep ${ }^{(b)}$ & Monovalent & 2 & Istituto Zooprofilattico Sperimentale \\
\hline & & & & dell'Abruzzo e del Molise, G. Caporale, \\
\hline & & & & Teramo, Italy \\
\hline \multirow[t]{9}{*}{ Attenuated (freeze-dried) } & Sheep ${ }^{(c)}$ & Monovalent & Series of three separate injections & Onderstepoort Biological Products, \\
\hline & & & with different serotypes & Onderstepoort, South Africa \\
\hline & & & in each bottle (d) & \\
\hline & & Polyvalent & (Can be produced on request ${ }^{(e)}$ ) & \\
\hline & Sheep & Monovalent & 4 & Central Veterinary Control \& Research \\
\hline & & & & Institute, Ankara, Turkey \\
\hline & Sheep & Monovalent & 4 & Biopharma, Rabat, Morocco \\
\hline & Sheep and goats & Monovalent & 10 & Colorado Serum Co., Denver, Colorado, \\
\hline & & & & Unites States of America \\
\hline
\end{tabular}

a) Indications for efficacy in cattle (94)

b) Immunogenicity was assessed by subcutaneously inoculating sheep, goats and bovines but only vaccinated sheep were challenged (15)

c) Indications for efficacy in cattle (65)

d) The vaccine is presented as: $A(1,4,6,12$ \& 14 serotypes); $B(3,8,9$, 10 \&11 serotypes) and C $(2,5,7,13$, \& 19 serotypes)

e) Production of these vaccines requires two months for production and quality control (45)

\section{Table IV}

\section{Advantages and disadvantages of a bluetongue vaccination strategy using attenuated vaccines}

\begin{tabular}{|c|c|c|c|}
\hline Advantages & Reference & Disadvantages & Reference \\
\hline Provision of an alternative to slaughter policies, which are & 76 & Risk of disease & 110 \\
\hline becoming less and less popular & & Risk of reversion to virulence & 18 \\
\hline $\begin{array}{l}\text { Reduction of the intensity and duration of viraemia following } \\
\text { contact between vaccinated animals and wild-type strains }\end{array}$ & 39,41 & $\begin{array}{l}\text { Risk of reassortment of genome segments between } \\
\text { vaccine and field viruses }\end{array}$ & $90,95,96$ \\
\hline of the bluetongue virus (progressive reduction of BTV & & Risk of foetal abnormalities (a) & 32 \\
\hline transmission) & & Risk of introducing exotic serotypes into an ecosystem & 59 \\
\hline Decrease in direct losses (number of outbreaks and & $39,41,45$ & if using polyvalent vaccines (b) & \\
\hline diseased animals, mortality) & & Risk of inappropriate coverage in susceptible species & 39 \\
\hline \multirow[t]{3}{*}{ Decrease in indirect losses (exportation of live animals) } & 39 & (at least $80 \%$ of the population) ${ }^{(c)}$ & \\
\hline & & $\begin{array}{l}\text { Risk of inappropriate coverage of all susceptible domestic } \\
\text { ruminant species (not only sheep) }\end{array}$ & 40,59 \\
\hline & & $\begin{array}{l}\text { Costs of the implementation and monitoring of the } \\
\text { vaccination programme (serological, virological and } \\
\text { entomological surveillance) }\end{array}$ & 119 \\
\hline
\end{tabular}

a) This disadvantage is easily resolved because the manufacturer does not recommend this vaccine for use in pregnant animals (18)
b) The most commonly used vaccines are those produced by Onderstepoort Biological Products Ltd, South Africa. A monovalent bluetongue vaccine is only produced on special request and its production and quality control take two months (45)

c) This disadvantage is easily resolved by proper implementation and monitoring of the vaccination programme

BTV: bluetongue virus 
vaccinate susceptible animals and limit contact between susceptible hosts and insect vectors (18).

Live attenuated vaccines have been available for many years $(18,94,110)$. Inactivated vaccines have been developed, but currently are less used (16) and recombinant vaccines (83) are still under development (56) (Table III).

\section{Attenuated vaccines}

In South Africa, around eight million doses of attenuated vaccines are used annually $(18,20)$. These vaccines are cheap, easy to produce and effective in controlling clinical outbreaks of BT in areas of endemic disease $(18,20)$. They replicate in sheep without causing significant clinical effects and provide protection (humoral and cellular responses) against challenge with virulent virus of the same serotype (70). The vaccines most commonly used are those produced by Onderstepoort Biological Products Ltd, South Africa (45). Sheep are vaccinated three times every year at three-week intervals with vaccines containing five serotypes each. As one of the side effects of these vaccines is abortion, the last vaccination round has to be carried out three weeks before the mating period (18). Very few solid data have been published on the safety and efficacy of these vaccines $(18,45,50,65,66,67)$. Potential safety issues associated with attenuated vaccines, although probably not likely to occur often (no quantitative studies), are the following:

- risk of foetal abnormalities

- risk of reassortment

- risk of reversion to virulence

- risk of transmission of vaccine strains by vector midges (Table IV).

Some attenuated BT vaccine strains were shown to be teratogenic in sheep when administered during the first half of pregnancy (32). Attenuated BTV vaccine strains may be responsible for spontaneous cases of BTV-induced malformation in both sheep and cattle, but it is noted that different serotypes of BTV differ in their pathogenesis, transmissibility and growth characteristics (18). This risk must be avoided by clear indication on the product label that pregnant ewes must not be vaccinated in the first half of pregnancy.

The reassortment of genome segments between vaccine and field viruses has been demonstrated in the laboratory, but only rarely has it been reported to occur in the field $(14,46,71,89,90,95,96)$. The reassortment often involves segments of different serotypes of the vaccine (110). The effect of such reasortmens in dually infected vectors and/or hosts could result in altered virus characteristics and virulence (110). However, the risk of reassortment in the vertebrate and/or invertebrate hosts will be minimised if the interval between the recommended vaccination period (late winter, early spring) and the BT season (especially summer) is respected; this would make the incidence of co-circulating vaccine and virulent wild-type viruses unlikely. The number of possible reassortments in the case of BTV, which has ten segments, increases with the number of cocirculating serotypes (e.g. 1,024 for two serotypes [210] and 59,049 for three serotypes [310]) (18). Reassortment occurred during the recent 1998-2005 BTV outbreaks in Europe (56).

The release and transmission of attenuated virus into the environment may also result in a reversion to virulence through reassortment with a wild-type strain (18).

The possibility that insects could acquire vaccine virus by feeding on vaccinated animals and transmit it to sheep or cattle cannot be eliminated $(18,70)$. The minimum viraemia in infected animals necessary for successful vaccine virus dissemination by biting midges remains to be determined, although Fu et al. (37) have shown that only $12 \%$ of competent vector Culicoides sonorensis that were fed on blood containing 106-7 TCID50/ml were able to become persistently infected and to transmit the virus through saliva (42). However, the bite of only one infected competent midge vector is sufficient to induce transmission to susceptible ruminants $(72,73)$. Moreover, the vaccine virus serotype- 2 was also detected recently in areas not included in the vaccination campaign (30). The possible circulation of this vaccine virus poses problems that have to be considered if vaccination with attenuated strains is the strategy of choice, particulary if the zone where vaccination is carried out is bordered by territories free from disease/infection (30).

Lastly, attenuated vaccines were traditionally produced using eggs, so allergy cases could not be excluded $(2,88)$. Currently they are produced in cell culture $(18,20)$ and this risk decreases.

\section{Inactivated virus vaccines}

To avoid the problems listed above, inactivated vaccines have been developed (16). Recently, two new inactivated vaccines against BTV2 and BTV4 were developed and similar vaccines against other BTV serotypes are in the final stages of development (94). However, limited reports are currently available on the effectiveness of these new vaccines in the field $(15,119)$.

\section{Recombinant vaccines}

Recombinant DNA technology has provided novel approaches to developing intrinsically safe vaccines. This 
technology involves the synthesis of immunogenic proteins and particles that elicit highly protective immune responses. Protein engineering systems have been utilised to synthesise individual bluetongue virus proteins and core- (single coat) and viral-like (double coat) multiprotein structures (CLPs, VLPs). These engineered particles mimic the virus particles, but do not contain any genetic materials $(35,36,78)$. These recombinant vaccines have been tested successfully in vitro and under experimental conditions $(83,84,107)$. Together with a suitable diagnostic test to detect antibodies against viral proteins not present in the vaccine a new BTV vaccine would allow the distinction between vaccinated and infected animals (marker vaccines) (20). In addition, deliberate release of any organism containing recombinant DNA into the environment should be subject to review and approval by competent authorities (33).

It is necessary to develop an inactivated vaccine or a vaccine based on more advanced technology that would not only have the potential to effectively control the disease but that would also facilitate trade, because the virus circulating in live animals can be detected (117). Because of the small commercial market, vaccine manufacturers may need some public funding to achieve this objective (20).

\section{Creating and developing an early warning system for emerging animal diseases}

One objective of the vaccination strategy in endemic BT areas is to reduce the intensity and duration of viraemia in susceptible animal populations (39).

To resort to vaccination requires a fast, argued and concerted decision. Any delay in the detection of the disease reduces the anticipated vaccine protection. Indeed, without early detection, emergence can pass unperceived unless amplification of viral multiplication and transmission reveals it. Detection is often too late from the point of view of risk control, particularly if the disease, before expressing itself clinically, passes through an incubation period allowing transmission to the sensitive population by means of vectors (known or unknown) present in the environment (4) and via the sale of animals outside contaminated areas. The improvement of identification tools and an increase in the speed of detection are essential (25). The clinical approach to the detection of emergence must be favoured because for a new disease no laboratory test is available to ensure its detection at the moment of emergence (87). In addition, for exotic diseases, the cost of specific analyses can be prohibitive in view of the need for immediate detection of an emergence (e.g. the considerable cost of the quantitative real-time reverse transcription polymerase chain reaction [Rt-RT-PCR] for the detection of the BTV).

\section{Regulatory issues surrounding the temporary authorisation of animal vaccination}

A marketing authorisation for a veterinary vaccine is granted after an assessment of the quality, safety and efficacy of the product has been carried out in accordance with legal standards $(18,27,29,48)$. In order to fulfil the necessary criteria, data from all phases of the product development are evaluated against these key elements. Under the standard licensing process, the evaluation includes:

- complete characterisation and identification of seed material and ingredients

- laboratory and host animal safety and efficacy studies

- stability studies

- post-licensing monitoring of field performance (48).

This comprehensive evaluation may not be possible during the emergence of a new animal disease, but several mechanisms exist to allow for the availability of products in an emergency animal health situation, including:

- autogenous biologics

- conditional licenses

- experimental and emergency use authorisations

- the importation of products in use elsewhere in the world

- pre-approved vaccine banks (Table V) $(27,29,31,47$, $48,49)$.

Even when using the accelerated assessment procedure and conditional marketing authorisation procedure for a new medical product it can take up to five months to obtain an opinion concerning the granting of a European authorisation (26). Even in an emergency situation it can still take a long time.

However, Member States are still authorised to use vaccines without a marketing authorisation in an emergency situation and, in this case, the European Commission must be informed $(27,29)$. This procedure has been used successfully for bluetongue in the Mediterranean endemic area (8, 21, 39, 119). The vaccination strategy was mainly based on the use of the monovalent or polyvalent attenuated vaccines produced by 


\section{Table V \\ Legislation governing the mechanisms which allow for the use of vaccines without marketing authorisation in the United States of America and in the European Union in the case of an emerging disease}

(adapted from 48)

\begin{tabular}{|c|c|c|}
\hline Mechanism & United States of America & European Union \\
\hline Approval of experimental products(a) & $\begin{array}{l}\text { Title } 9 \text { of the Code of Federal Regulations }{ }^{(b)} \text { Part } 103.3 \\
\text { (porcine reproductive and respiratory syndrome) }\end{array}$ & No specific legislation \\
\hline \multicolumn{3}{|l|}{ Use of autogenous biologics } \\
\hline Attenuated & No specific legislation & Directive 2001/82/EC, article 4 (27) \\
\hline Inactivated & $\begin{array}{l}\text { Title } 9 \text { of the Code of Federal Regulations Part } 113.113^{\text {(c) }} \\
\text { (infectious salmon anaemia virus) }\end{array}$ & No specific legislation \\
\hline Conditional Product Licences (d) & Title 9 of the Code of Federal Regulations Part 102.6 (West Nile virus) & $\begin{array}{l}\text { Regulation 2004/726/EC, article } 39 \\
\text { (centralised procedure) (29) } \\
\text { Directive 2001/82/EC, article } 26 \\
\text { (other procedure) (27) }\end{array}$ \\
\hline $\begin{array}{l}\text { Importation of products in use } \\
\text { elsewhere in the world }(\mathrm{e})\end{array}$ & Title 9 of the Code of Federal Regulations Part 104 (rabbit calicivirus) & Directive 2004/28/EC, article 8 (28) \\
\hline Vaccine bank ${ }^{(f)}$ & No specific regulation (foot and mouth disease) & Decision 2001/433/EC, article $3^{\text {(g) }}$ (bluetongue) (21) \\
\hline Other ${ }^{(h)}$ & Title 9 of the Code of Federal Regulations Part 106.1 & Directive 2004/28/EC, article 8 (28) \\
\hline \multicolumn{3}{|c|}{$\begin{array}{l}\text { a) Experimental production, distribution and evaluation of biological products may be authorised prior to licensing under very specific circumstances } \\
\text { b) Title } 9 \text { of the Code of Federal Regulations (http://www.aphis.usda.gov/vs/cvb/html/cfr.html) (106) } \\
\text { c) According to this act, they are prepared from cultures of micro-organisms which have been inactivated and are non-toxic under certain circumstances } \\
\text { d) Conditional licences are authorised under very specialised circumstances to meet an emergency condition, limited market, local situation, or other special circumstance. Licences are issued } \\
\text { under an accelerated procedure which assures purity, safety and efficacy of the products involved } \\
\text { e) Permits for biological products imported into the considered country may be authorised for a variety of purposes. In each case, a separate veterinary biological product permit is required for } \\
\text { each shipment of biological product to be imported } \\
\text { f) No specific regulations exist for the creation and maintenance of a vaccine or seed bank } \\
\text { g) Under very specific circumstances, biological products may be exempted from one or more of the requirements. These circumstances are warranted if products will be used by or under the } \\
\text { supervision or control of the competent authority in the prevention, control or eradication of animal diseases in connection with an official programme or an emergency animal disease } \\
\text { situation, or an experimental use of the product by the Authority } \\
\text { h) In general, European legislation concerning the disease must specify the use of vaccination. In this case, the European Commission can propose the constitution of a vaccine bank with a } \\
\text { proposal for a European decision }\end{array}$} \\
\hline
\end{tabular}

Onderstepoort Biological Products Ltd (South Africa) and to a lesser extent on the inactivated vaccine produced by Mérial SAS in Lyons, France (8, 39, 119).

Epidemiological surveillance of BT in this vaccination context requires the following tasks:

a) clear communication all along the process

b) a description of the prevalent epidemiological situation

c) the choice of an appropriate national response strategy

d) the choice of an appropriate vaccine

e) verification of the quality of the vaccine used

f) strict adherence to the vaccination protocol and initiation and maintenance of a system allowing registration, delivery and follow-up of vaccination

g) evaluation of the necessary level of vaccination coverage h) monitoring, analysis and possible adjustment of field implementation of the vaccination.

Each of these points is described in more detail below. This information is also useful for replacing the temporary authorisation by a complete authorisation as quickly as possible.

\section{Clear communication throughout the process}

Communication is the rational process of conveying a representative picture of objects or situations when having to perform a concerted action with several partners (51). Several levels of communication should be maintained (i.e. inside and outside of the epidemiological network). Concerning international trade, clear and immediate communication in the framework of animal disease notification is essential to limit the spread of the disease (e.g. the OIE World Animal Health Information System) and to ensure mutual trust between countries. Clear communication about uncertainties in all phases of the decision process is also important. 


\section{Describing the prevalent epidemiological situation}

A description of the true epidemiological situation is a prerequisite before any action can be undertaken, because this knowledge is needed to choose the appropriate strategic option(s), including vaccination. This description requires the incorporation of detailed information concerning the following:

- suspected and confirmed clinical cases of BT (e.g. reason for the visit, date of suspicion, date of first infection, animal species involved, clinical signs, laboratory diagnosis)

- outbreaks (e.g. species concerned, number and size of herds, location of herds, mortality rate, morbidity rate)

- vector (e.g. date and location of trapping, number of Culicoides identified)

- virus activity (e.g. date and location of sampling, number of animals sampled, number of animals at risk and number of animals seroconverted)

- boundaries and subdivision boundaries

- geography and climate (e.g. vegetative index, temperature, rainfall) $(10,41,119)$.

\section{Choosing an appropriate national response strategy}

Risk assessment is a tool advocated by the World Trade Organization in the context of trade policy (Agreement on the Application of Sanitary and Phytosanitary Measures). The methodology can also be used to assist in the choice of an appropriate national response strategy following an incursion of bluetongue (40). The choice of strategy should be made after an independent, scientific and collective assessment in which the range and magnitude of consequences of implementing or not implementing a vaccination programme of all susceptible domestic livestock in the affected regions is considered (scenario analysis). This methodology was used in Italy before initiating vaccination of all susceptible domestic ruminant species in infected areas and areas surrounding them (protection zone). Under the relevant Italian conditions, the model predicted that at least $80 \%$ of susceptible livestock should be immunised for vaccination to be effective (39). Such risk assessment should be conducted taking into account current scientific knowledge, the particular local situation and uncertainties about the parameters used in the model.

In addition, decision trees are often used to clarify the path to appropriate vaccine usage. Analysis includes evaluation of several parameters, such as the probability of exposure to the infectious agent, the efficacy and safety of the product, its availability and cost, and consequences of vaccination. If a vaccinated animal cannot be differentiated from an infected animal, further animal movement controls may need to be considered (33).

\section{Choosing an appropriate vaccine}

The choice of vaccine should be made taking into account the epidemiological situation of BT in the country or territory concerned (e.g. BTV serotype(s)) and in accordance with current knowledge about the advantages and disadvantages of the bluetongue vaccination strategy (Table IV) and the availability on the world market of the vaccines being considered (94) (Table III). Information concerning the quantity of BT vaccines deemed necessary in the case of emergency vaccination should be available in the contingency plan of each Member State (23).

\section{Verifying the quality of the vaccine used}

The quality of the vaccine used must be verified. Results of experimental infection with the chosen vaccine and subsequent challenge with the field strain BTV should be collected. Information concerning the safety and efficacy of the vaccine is required and help in the interpretation of serology and virology results after vaccination may be necessary $(45,67)$.

\section{Adhering to the vaccination protocol and maintaining a system allowing registration, delivery and follow-up of vaccination}

It is vital to strictly follow the manufacturer's instructions and to quickly administer the doses after reconstitution of the freeze-dried vaccine. The storage conditions of vaccine are very important (isotherm box): a rapid decrease of infectious virus titre is observed after a few hours at ambient temperature (45). This observation could explain some apparent vaccine failure in the field.

As with every veterinary medical product the traceability of vaccine doses must be assured at local, regional and national level. The following details must be entered into a vaccine management information system, as without them it is not possible to correctly estimate vaccine coverage (39):

- vaccine serotype(s)

- vaccine batch numbers

- farm codes

- total numbers of animals on the farm

- numbers of target animals

- numbers of vaccinated animals by species

- vaccination date. 


\section{Evaluating the necessary level of vaccination coverage}

It is important to evaluate the level of vaccination coverage that should be attained to eradicate the disease. An empirical evaluation gives a herd immunity threshold (HIT) value of $75 \%$ (Charles Nicolle's law) but it has been shown that HIT calculation should be based on the evaluation of the rate of spread of the disease measured by the basic reproductive number $\mathrm{R}_{0}$, i.e. the average number of secondary infections produced by one infected individual introduced into a fully susceptible population (1). Basically, if $\mathrm{R}_{0}<1$, the disease cannot persist in a population. It can be shown that the proportion of animals to be vaccinated in a naïve population must exceed $1-1 / R_{0}$ in order to reduce $\mathrm{R}_{0}$ to a value below 1 . It is noted that for vector-borne diseases, several factors attributable to the vector will change the classical approach (e.g. biting rate, trophic preferences, survival rate, incubation period and vectorial competency, i.e. capacity for the virus to develop in the vector). Consequently, even with high vaccination coverage, it is still possible that the virus will persist in small areas or in reservoir animals. There is then a risk of re-emergence when coverage declines (38).

The relationship between vaccination coverage of the target populations and animal losses due to disease and virus circulation must be analysed.

\section{Monitoring, analysis and possible adjustment of field vaccination}

In order to monitor the progress of the vaccination campaign in the infected zone and verify the immune status of vaccinated herds (coverage), a random sample of vaccinated animals in each grid cell should be tested for antibodies (39).

All clinical suspicion must be investigated to confirm whether or not BTV is present. In the case of viral detection and isolation, serotyping of BTV is performed (e.g. by seroneutralisation test) to verify possible new strain introductions into the territory. In this case, the vaccination programme must be promptly adapted (119). If possible, an RT-PCR test should be carried out to differentiate between the wild type and vaccine viruses (8). In addition, strain genotyping permits the study of the molecular epidemiology of BT and the monitoring of possible reassortment of genome segments between vaccine and field viruses (7).

The vaccination programme must be maintained until there is proof that the virus is no longer circulating. Once the clinical signs disappear the absence of BTV circulation in the vaccinated populations must be verified. In order to do this, a longitudinal study of representative sentinel herds in the risk area is performed. Because vaccinated animals are seropositive, subpopulations that are included in the study must be unvaccinated animals (e.g. young animals sampled when prophylactic treatment is administered or in slaughterhouses). Blood samples from sentinel herds should be collected using a statistically based sampling frame, with the frequency of collection depending upon the season and infection occurrence in the area.

Entomological surveillance is performed by trapping midges in areas of ecological importance in order to monitor the spread and seasonal dynamics of Culicoides spp. (39, 119). The presence of field BTV and vaccine virus (when using attenuated vaccine) must be investigated. The possibility that midges could acquire vaccine virus by feeding on vaccinated animals and transmit it to unvaccinated animals should also be investigated, in particular, with regards to territories that are free from disease/infection but border zones where vaccination is carried out (30).

\section{Conclusions and recommendations}

In the case of an emerging disease (e.g. bluetongue), the decision by national authorities to include temporary authorisation of a non-registered animal vaccine in disease control strategies requires scientific, economic, technical, social and risk analysis support. Advantages and disadvantages of the vaccination option strategy (Table IV) should be taken into account, as well the regulatory aspects (Table V), the biology and the epidemiology of the disease, the structure and efficacy of the epidemiological network and the economic and social impacts. Moreover, in the case of a zoonotic disease, factors affecting humans become a priority. Use of decision trees should also be encouraged.

For safety reasons inactivated or other more technologically advanced vaccines should be preferred because they have the potential not only to effectively control the disease but also to allow trade due to detection of virus circulation in live animals. The development of marker vaccines is the correct choice for manufacturers, but national authorities and supra-national organisations should stimulate early development of these new vaccines (including bank vaccines) with the aim of delivering them quickly to reduce pathogen circulation in an emerging situation. Listing and prioritisation of diseases of major concern (i.e. diseases which can have a severe impact on human/animal health or on the economy) should be the first step, for which an understanding of the accuracy of the estimation of the true prevalence of disease is essential. 
The latter depends on the presence and quality of the epidemiologic network and on clearly and swiftly notifying the disease to the appropriate authorities (e.g. information promptly entered into the OIE World Animal Health Information System and into the Centralized Information System for Infectious Diseases of the World Health Organization). The second step should be to find out about existing patents and to develop a map showing the locations of research laboratories, technology facilities and manufacturers to be used by competent authorities in case of emerging diseases. The third step should be to identify gaps and important weaknesses in available tools and sources. The fourth step should be to develop a proposition to focus research on priority animal disease so as to increase the knowledge base and product availability for these diseases (94).

When applying this vaccination strategy several factors should be evaluated collectively, including:

- communication

- prevalent epidemiological situation

- response strategy to the disease

- appropriateness of the vaccine used

- adherence to vaccination protocol and maintenance of a system allowing registration, delivery and follow-up of vaccine
- level of vaccination coverage

- analysis and possible adjustment of field vaccination.

This information is useful for replacing the temporary authorisation with a complete authorisation.

It is also necessary to continuously adapt the vaccination programme to the epidemiological situation. This adaptation requires the collaboration of all stakeholders and needs to include independent and collective scientific advice.

Finally, the concept of temporary authorisation can easily be transposed for use with emerging zoonotic diseases and may assist in improving relationships between different Veterinary Services worldwide and it is an excellent way to build the necessary capacity to respond to emerging diseases.

\section{Acknowledgements}

The authors wish to thank P. Houdart (Federal Agency for the Safety of the Food Chain) for help in accessing data originating from the European Commission's Animal Disease Notification System and R. De Deken and M. Madder (Institute for Tropical Medicine) for use of the photo of $C$. dewulfi.

\title{
Questions réglementaires liées à l'autorisation temporaire de vacciner les animaux en situation d'urgence : I'exemple de la fièvre catarrhale du mouton en Europe
}

\author{
C. Saegerman, M. Hubaux, B. Urbain, L. Lengelé \& D. Berkvens
}

\begin{abstract}
Résumé
L'autorisation de mise sur le marché des vaccins vétérinaires est accordée dès lors que la qualité, l'innocuité et l'efficacité du produit ont été évaluées conformément aux normes réglementaires. Cette évaluation comprend la caractérisation exhaustive suivie de l'identification des semences et des ingrédients utilisés, l'évaluation de la sécurité pour le laboratoire et pour l'espèce hôte, ainsi que des études d'efficacité, un suivi après la mise sur le marché et un contrôle des performances sur le terrain. Cette évaluation n'est pas toujours réalisable en cas d'émergence d'une nouvelle maladie animale, mais il existe plusieurs mécanismes permettant de disposer de produits dans des
\end{abstract}


situations d'urgence zoosanitaire : autovaccins, autorisations de mise sur le marché sous condition, autorisations limitées aux expérimentations ou aux situations d'urgence, importation de produits utilisés en d'autres endroits du monde, banques de vaccins pré-enregistrés. Les auteurs décrivent les questions réglementaires liées à l'autorisation temporaire de vacciner les animaux, en prenant l'exemple de l'émergence de la fièvre catarrhale du mouton en Europe. Plusieurs conditions doivent être réunies avant de délivrer une autorisation temporaire : le vaccin doit être à virus inactivé afin d'empêcher tout risque de réversion vers la virulence ou de réassortiment entre les souches vaccinales et/ou les souches sauvages du virus de la fièvre catarrhale du mouton ; les décisions en la matière doivent être justifiées scientifiquement et se fonder sur une analyse du risque ; les animaux susceptibles ayant été vaccinés doivent être rigoureusement recensés; les protocoles de vaccination doivent être connus et respectés ; un dispositif doit être en place pour l'enregistrement, l'administration et le suivi de la vaccination, ainsi que pour le suivi, l'analyse et d'éventuelles corrections dans l'utilisation de la vaccination sur le terrain. Cette autorisation temporaire doit être remplacée aussi rapidement que possible par une autorisation régulière.

\title{
Mots-clés
}

Autorisation temporaire - Maladie émergente - Question réglementaire - Santé animale - Vaccin - Vaccination.

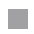

\section{Cuestiones de reglamentación en torno a la autorización temporal de vacunación de animales en situaciones de emergencia: el ejemplo de la lengua azul en Europa}

\author{
C. Saegerman, M. Hubaux, B. Urbain, L. Lengelé \& D. Berkvens
}

\section{Resumen}

Para autorizar la comercialización de una vacuna veterinaria es preciso que previamente se hayan evaluado su calidad, inocuidad y eficacia conforme a la normativa vigente. Ello comprende la descripción y caracterización completa del material y los ingredientes de partida, los estudios de inocuidad para los animales hospedadores y de laboratorio y los estudios de eficacia y estabilidad, así como el control del rendimiento del producto sobre el terreno una vez obtenida la licencia. Aunque todo este proceso puede resultar impracticable en el momento en que se manifiesta una nueva enfermedad animal, existen varios mecanismos para asegurar el suministro de productos en el curso de una emergencia zoosanitaria, por ejemplo productos biológicos autógenos, licencias condicionales, autorizaciones de uso experimental y de emergencia, importación de productos utilizados en otras partes del mundo y bancos de vacunas preaprobadas. Utilizando el ejemplo de la aparición de la lengua azul en el Norte de Europa, los autores exponen las cuestiones de reglamentación que se plantean respecto a la autorización temporal de vacunación de animales. 
Para otorgar una autorización temporal se exige el cumplimiento de varias condiciones, por ejemplo: el uso de vacunas inactivadas para evitar la posibilidad de reversión a la virulencia o de reordenamiento entre virus vacunales $y / 0$ cepas salvajes del virus de la lengua azul; la existencia de pruebas científicas y análisis de riesgos que respalden la adopción de decisiones; la existencia de un censo completo de los animales sensibles que hayan sido vacunados; el cumplimiento de los protocolos de vacunación; y la existencia de un mecanismo que permita registrar y aplicar las vacunaciones, supervisar sus efectos y controlar, analizar y eventualmente ajustar la administración de vacunas sobre el terreno. Esta autorización temporal debe ser sustituida lo antes posible por una autorización completa.

\section{Palabras clave}

Autorización temporal - Enfermedad emergente - Problema de reglamentación Sanidad animal - Vacuna - Vacunación.

\section{References}

1. Anderson R.M. \& May R.M. (1991). - Infectious diseases of humans: dynamics and control. Oxford University Press.

2. Anon. (1996). - Pharmacovigilantie: anaphylaxie bij runderen. Onverenigbaarheid tussen vaccins en antibiotica: mogelijke aanleiding tot ernstige shockreacties [Pharmacovigilance. Anaphylaxis in bovines incompatibility of vaccines and antibiotics: a possible reason for severe allergic reactions]. Press release from Mycofarm, Boehringer, Pfizer and Vétoquinol. Mycofarm, Turnhout, 3 pp.

3. Anon. (1998). - Report on the incursion and evolution of bluetongue in Greece in 1998. Ministry of Agriculture, DG of Veterinary Services, Department of Infectious Diseases, Greece.

4. Barnouin J. \& Vourch G. (2004). - Les maladies émergentes : un défi pour le développement durable des productions animales. INRA Prod. anim., 17 (5), 355-364.

5. Benkirane A. (2001). - Surveillance épidémiologique et prophylaxie de la brucellose des ruminants : l'exemple de la région Afrique du Nord et Proche-Orient. Rev. sci. tech. Off. int. Epiz., 20 (3), 757-767.
6. Braverman Y., Chizov-Ginzburg A., Pener H. \& Wilamowski A. (2004). - Susceptibility and repellency of Culicoides imicola and Culex pipiens to lambda-cyhalothrin. Vet. ital., 40 (3), 336-339.

7. Bréard E., Hamblin C., Hammoumi S., Sailleau C., Dauphin G. \& Zientara S. (2004). - The epidemiology and diagnosis of bluetongue with particular reference to Corsica. Res. vet. Sci., 77, 1-8.

8. Bréard E., Sailleau C., Coupier H., Mure-Ravaud K., Hammoumi S., Gicquel B., Hamblin C., Dubourget P. \& Zientara S. (2003). - Comparison of genome segments 2 , 7 and 10 of bluetongue viruses serotype 2 for differentiation between field isolates and the vaccine strain. Vet. Res., 34, 777-789.

9. Brown C. (2001). - Importance des maladies émergentes pour la santé publique et animale et pour les échanges commerciaux. 69th General Session of the International Committee of the World Organisation for Animal Health (OIE), 27 May-1 June, Paris, document 69 SG/9. OIE, Paris, 6 pp. 
10. Cameron A.R. (2004). - The impact of current and proposed changes to general guidelines on bluetongue surveillance of the Office International des Epizooties. Vet. ital., 40 (4), 693-696.

11. Caracappa S., Torina A., Guercio A., Vitale F., Calabro A., Purpari G., Ferrantelli V., Vitale M. \& Mellor P.S. (2003). Identification of a novel bluetongue virus vector species of Culicoides in Sicily. Vet. Rec., 153 (3), 71-74.

12. Center for Veterinary Biologics (CVB) (2006). - Code of Federal Regulations, Title 9 - Animals and Animal Products, Parts 101 to 123. Ames, Iowa, United States of America. Available at http://www.aphis.usda.gov/vs/cvb/html/cfr.html (accessed on 28 October 2006).

13. Centers for Disease Control and Prevention (CDC) (1998). Preventing emerging infectious diseases. A strategy for the 21st Century. Center for disease control and prevention, US Department of health and human services, Atlanta, Georgia, October.

14. De Mattos C.C., de Mattos C.A., Osburn B.I. \& MacLachlan N.J. (1994). - Heterogeneity of the L2 gene of field isolates of bluetongue virus serotype 17 from the San Joaquin Valley of California. Virus Res., 31, 67-87.

15. Di Emidio B., Nicolussi P., Patta C., Ronchi G.F., Monaco F., Savini G., Ciarelli A. \& Caporale V. (2004). - Efficacy and safety studies on an inactivated vaccine against bluetongue virus serotype 2. Vet. ital., 40 (4), 640-644.

16. Dubourget P. \& Bolon A. (2005). - Inactivated bluetongue vaccine. Workshop: EU funded research in bluetongue, 10-11 March, Brussels, Belgium.

17. Dulac G.C., Dubuc C., Myers D.J., Afshar A. \& Taylor E.A. (1989). - Incursion of bluetongue virus type 11 and epizootic haemorrhagic disease of deer type 2 for two consecutive years in the Okanagan Valley. Can. vet. J., 30, 351.

18. Dungu B., Gerdes T. \& Smit T. (2004). - The use of vaccination in the control of bluetongue in southern Africa. Vet. ital., 40 (4), 616-622.

19. Enserink M. (2006). - Emerging infectious diseases. During a hot summer, bluetongue virus invades northern Europe. Science, 313 (5791), 1218-1219.

20. European Commission (2000). - Possible use of vaccination against bluetongue in Europe. Report of the Scientific Committee on Animal Health and Animal Welfare. Health \& Consumer Protection Directorate-General. Adopted 27 June. Doc. Sanco/C3/AH/R19/2000.

21. European Commission (2001). - Decision 2001/433/EC of 21 May 2001 for purchase by the Community of bluetongue vaccine and restocking of the Community bank. Off. J. Eur. Communities, L 154, 61-62.

22. European Council (1981). - Council Directive 81/852/ECC on the approximation of the laws of the Member States relating to analytical, pharmacotoxicological and clinical standards and protocols in respect of the testing of veterinary medicinal products. Off. J. Eur. Communities, L 317, 53-98.
23. European Council (2000). - Directive 2000/75/EC of 20 November, laying down specific provisions for the control and eradication of bluetongue. Off. J. Eur. Communities, L 327, 74-83.

24. European Food Safety Authority (EFSA) (2006). Bluetongue serotype 8 epidemic bulletin by EFSA epidemiology working group. Available at: http://www.efsa. europa.eu/en/in_focus/bluetongue/outbreak_overview.html (accessed on 28 October 2006).

25. European Food Safety Authority (EFSA) (2006). - Opinion of the Scientific Committee on a request from EFSA related to the early identification of emerging risks. EFSA J., 375, 1-14.

26. European Medicines Agency (2006). - Guideline on the procedure for accelerated assessment pursuant to article 39 (8) of regulation (EC) No. 726/2004. Committee for Medicinal Products for Veterinary Use, London, United Kingdom, 18 May. Doc. Ref. EMEA/CVMP/32995/2006.

27. European Parliament and the European Council (2001). Directive 2001/82/EC of 6 November 2001 on the Community code relating to veterinary medicinal products. Off. J. Eur. Communities, L 311, 1-66.

28. European Parliament and the European Council (2004). Directive 2004/28/EC of 31 March 2004 amending Directive 2001/82/EC on the Community code relating to veterinary medicinal products. Off. J. Eur. Communities, L 136, 58-84.

29. European Parliament and the European Council (2004). European Regulation 726/2004/EC of 31 March 2004 laying down Community procedures for the authorisation and supervision of medicinal products for human and veterinary use and establishing a European Medicines Agency. Off. J. Eur. Communities, L 136, 58-84.

30. Ferrari G., De Liberato C., Scavia G., Lorenzetti R., Zini M., Farina F., Magliano A., Cardeti G., Scholl F., Guidoni M., Scicluna M.T., Amaddeo D., Scaramozzino P. \& Autorino G.L. (2005). - Active circulation of bluetongue vaccine virus serotype 2 among unvaccinated cattle in central Italy. Prev. vet. Med., 68 (2-4), 103-113.

31. Février J. (2004). - European Union policy for the control and eradication of bluetongue. Vet. ital., 40 (4), 682.

32. Flanagan M. \& Johnson S.J. (1995). - The effects of vaccination of Merino ewes with an attenuated Australian BTV serotype 23 at different stages of gestation. Aust. vet. J., $72,455-457$

33. Foley P.L. \& Hill R.E. Jr (2005). - Regulatory considerations for marker vaccines and diagnostic tests in the US. Biologicals, 33 (4), 253-256

34. Food and Agriculture Organization of the United Nations (FAO) (2000). - Preliminary data on veterinary vaccine production/needs in some countries of the Near East. FAO Regional Office for the Near East, Cairo, Egypt. 
35. French T.J., Marshall J.J. \& Roy P. (1990). - Assembly of double-shelled, viruslike particles of bluetongue virus by the simultaneous expression of four structural proteins. J. Virol., 64 (12), 5695-5700

36. French T.J. \& Roy P. (1990). - Synthesis of bluetongue virus (BTV) corelike particles by a recombinant baculovirus expressing the two major structural core proteins of BTV. J. Virol., 64 (4), 1530-1536.

37. Fu H., Leake C.J., Mertens P.P.C. \& Mellor P.S. (1999). - The barriers to bluetongue virus infection, dissemination and transmission in the vector, Culicoides variipennis (Diptera: Ceratopogonidae). Arch. Virol., 144, 747-761.

38. Gerbier G., Hendrikx P., Roger F., Zientara S., Biteau-Coroller F., Grillet C., Badler T. \& Albina E. (2004). - Bluetongue control using vaccines: experience of the Mediterranean islands. Vet. ital., 40 (4), 611-615.

39. Giovannini A., Calistri P., Nannini D., Paladini C., Santucci U., Patta C. \& Caporale V. (2004). - Bluetongue in Italy: Part II. Vet. ital., 40 (3), 252-259.

40. Giovannini A., MacDiarmid S., Calistri P., Conte A., Savini L., Nannini D. \& Weber S. (2004). - The use of risk assessment to decide the control strategy for bluetongue in Italian ruminant populations. J. Risk Anal., 24 (6), 1737-1753

41. Giovannini A., Paladini C., Calistri P., Conte A., Colangeli P., Santucci U., Nannini D. \& Caporale V. (2004). - Surveillance system of bluetongue in Italy. Vet. ital., 40 (3), 369-384.

42. Gomulski L.M., Meiswinkel R., Delecolle J.C., Goffredo M. \& Gasperi G. (2005). - Phylogeny of the subgenus Culicoides and related species in Italy, inferred from internal transcribed spacer 2 ribosomal DNA sequences. Med. vet. Entomol., 20 (2), 229-238

43. Guyot H., Mauroy A., Thiry E., Losson B., Bodmer M., Kirten P., Rollin F. \& Saegerman C. (2007). - Fièvre catarrhale ovine chez les ruminants. Description clinique des cas vécus dans le Nord de l'Europe durant l'été et l'automne 2006. Bulletin GTV, 39, 89-96.

44. Hallet L. (2003). - Les modes de collaboration entre vétérinaires officiels, vétérinaires privés et organisations d'éleveurs. In Veterinary Services: organisation, quality assurance, evaluation (E. Correa Melo \& F. Gerster, eds). Rev. sci. tech. Off. int. Epiz., 22 (2), 523-532.

45. Hammoumi S., Bréard E., Sailleau C., Russo P., Grillet C., Cetre-Sossah C., Albina E., Sanchis R., Pepin M., Guibert J.M. \& Zientara S. (2003). - Studies on the safety and immunogenicity of the South African bluetongue virus serotype 2 monovalent vaccine: specific detection of the vaccine strain genome by RT-PCR. J. vet. Med., B, infect. Dis. vet. public Hlth, 50 (7), 316-321.

46. Heidner H.W., Iezzi L.G., Osburn B.I. \& MacLachlan N.J. (1991). - Genetic variation and evolutionary relationships amongst bluetongue viruses endemic in the United States. Virus Res., 21, 91-109.
47. Hill R.E. (2004). - Regulation of conditionally licensed biologicals in the United States. Dev. Biol. (Basel), $117,147-152$.

48. Hill R.E., Foley P.L., Carr M.Y., Elsken L.A., Gatewood D.M., Ludeman L.R. \& Wilbur L.A. (2003). - Regulatory considerations for emergency use of non-USDA licensed vaccines in the United States. Dev. Biol. (Basel), 114, 31-52.

49. Hill R.E., Foley P.L., Carr M.Y., Elsken L.A., Gatewood D.M., Ludeman L.R. \& Wilbur L.A. (2005). - Regulatory considerations for emergency use of non-USDA licensed vaccines in the United States. Workshop: EU funded research in bluetongue, 10-11 March, Brussels, Belgium.

50. Hunter P. \& Modumo J. (2001). - A monovalent attenuated serotype 2 bluetongue virus vaccine confers homologous protection in sheep. Onderstepoort J. vet. Res., 68, 331-333.

51. Hupet P. (2002). - La communication relative au risque: principes généraux. Épidémiol. Santé anim., 41, 189-200.

52. Kettle D.S. (1962). - The bionomics and control of Culicoides and Leptoconops (Diptera, Ceratopogonidae Heleidae). Annu. Rev. Entomol., 7, 401-418.

53. King L.J. (2004). - Emerging and re-emerging zoonotic diseases: challenges and opportunities. Technical Item I. In Proc. 72nd General Session of the International Committee of the World Organisation for Animal Health (OIE), Paris, France, 23-28 May. OIE, Paris, Doc. 72 SG/9.

54. Kirkland P.D., Zhang N., Hawkes R.A., Li Z., Zhang F, Davis R.J., Sanders D.A., Li H., Zhang K., Ben J., He G.F., Hornitzky C.L. \& Hunt N.T. (2002). - Studies on the epidemiology of bluetongue virus in China. Epidemiol. Infect., $128,257-263$.

55. Le Gall F.G. (2006). - Economic and social justification of investment in animal health and zoonoses. Technical Item II. In Proc. 74th General Session of the International Committee of the World Organisation for Animal Health (OIE), Paris, France, 21-26 May 2006. OIE, Paris, Doc. 74 SG/10.

56. Lefèvre P.-C. \& Mellor P.S. (2007). - Bluetongue. In Infectious and parasitic disease of livestock. Lavoisier, Provigny, France, in press.

57. MacLachlan N.L. (1994). - The pathogenesis and immunology of bluetongue virus infection of ruminants. Comp. Immunol. Microbiol. infect. Dis., 17, 197-206.

58. Meiswinkel R. (2006). - The Culicoides vector of bluetongue disease in Limburg, the Netherlands. International Society for Infectious Diseases. Available at: www.promedmail.org (accessed on 28 October 2006).

59. Mellor P.S. (2005). - Development of a safe, efficacious bluetongue virus vaccination strategy for Europe. Workshop: EU funded research in bluetongue, 10-11 March, Brussels, Belgium. 
60. Mellor P.S. \& Boorman J. (1995). - The transmission and geographical spread of African horse sickness and bluetongue viruses. Ann. trop. Med. Parasitol., 89 (1), 1-15.

61. Mellor P.S., Boorman J. \& Baylis M. (2000). - Culicoides biting midges: their role as arbovirus vectors. Annu. Rev. Entomol., $45,307-340$

62. Mellor P.S. \& Wittmann E. (2002). - Bluetongue virus in the Mediterranean basin 1998-2001. Vet. J., 164, 20.

63. Mertens P.P.C., Attoui H. \& Bamford D.H. (eds) (2006). - The RNAs and proteins of dsRNA viruses. Institute for Animal Health, Pirbright. Available at: www.iah.bbsrc.ac.uk/dsRNA_ virus_proteins/Orbivirus.htm (accessed on 28 October 2006).

64. Miranda M.A., Borras D., Rincon C. \& Alemany A. (2003). Presence in the Balearic Islands (Spain) of the midges Culicoides imicola and Culicoides obsoletus group. Med. vet. Entomol., 17, 52-54.

65. Monaco F., Bonfini B., Zaghini M., Antonucci D., Pini A. \& Savini G. (2004). - Vaccination of cattle using monovalent modified-live vaccine against bluetongue virus serotype 2: innocuity, immunogenicity and effect on pregnancy. Vet. ital., 40 (4), 671-675.

66. Monaco F., De Luca N., Morelli D., Pisciella M., Palmarini S., Di Giandomenico M. \& Savini G. (2004). - Field vaccination of cattle using a bivalent modified-live vaccine against bluetongue virus serotypes 2 and 9: effect on milk production. Vet. ital., 40 (4), 661-663.

67. Monaco F., De Luca N., Spina P., Morelli D., Liberatore I., Citarella R., Conte A. \& Savini G. (2004). - Virological and serological response of cattle following field vaccination with bivalent modified-live vaccine against bluetongue virus serotypes 2 and 9. Vet. ital., 40 (4), 657-660.

68. Morse S.S. (1995), - Factors in the emergence of infectious diseases. Emerg. infect. Dis., 1, 7-15.

69. Morse S.S. (2004). - Factors and determinants of disease emergence. In Emerging zoonoses and pathogens of public health concern (L.J. King, ed.). Rev. sci. tech. Off. int. Epiz., 23 (2), 443-451.

70. Murray P.K. \& Eaton B.T. (1996). - Vaccines for bluetongue. Aust. vet. J., 73 (6), 207-210.

71. Oberst R.D., Stott J.L., Blanchard-Channell M. \& Osburn B.I. (1987). - Genetic reassortment of bluetongue virus serotype 11 strain in the bovine. Vet. Microbiol., 15, 11-18.

72. O'Connell L. (2001). - Transmission rates of bluetongue virus by Culicoides biting midges. In Proc. of the Royal Entomological Society International Symposium on insects and disease, 10-12 September, University of Aberdeen. Abstracts book.
73. O'Connell L. (2002). - Entomological aspects of the transmission of arboviral diseases by Culicoides biting midges. Ph.D. thesis of the University of Bristol, 176 pp.

74. Osburn B.I. (1994). - The impact of bluetongue virus on reproduction. Comp. Immunol. Microbiol. infect. Dis., 17, 189-196.

75. Panagiotatos D.E. (2005). - Review of bluetongue virus incursions, vectors, surveillance and epidemiological features in Eastern Europe in the period 1998-2004. Workshop: EU funded research in bluetongue, 10-11 March, Brussels, Belgium.

76. Pastoret P.-P. \& Mackay D. (2002). - Regulatory considerations for emergency use of vaccines in the European Union. Vaccines for OIE list A and emerging animal diseases, Scheman Conference Center, Ames, Iowa, USA, 16-18 September.

77. Pattison J. (1998). - The emergence of bovine spongiform encephalopathy and related diseases. Emerg. infect. Dis., 4 (3), 390-394.

78. Pearson L.D. \& Roy P. (1993). - Genetically engineered multi-component virus-like particles as veterinary vaccines. Immunol. Cell Biol., 71 (5), 381-389.

79. Purse B.V., Mellor P.S., Rogers D.J., Samuel A.R., Mertens P.P. $\&$ Baylis M. (2005). - Climate change and the recent emergence of bluetongue in Europe. Nat. Rev. Microbiol., 3 (2), 171-181.

80. Qin Q., Tai Z., Wang L., Luo Z., Hu J. \& Lin H. (1996). Bluetongue epidemiological survey and virus isolation in Xinjiang, China. In Bluetongue disease in Southeast Asia and the Pacific. Australian Centre for International Agricultural Research, Canberra, 67-71.

81. Rodhain F. (2003). - Emergences de maladies à transmission vectorielle. Épidémiol. Santé anim., 43, 33-49.

82. Roy P. (1992). - Bluetongue virus proteins. J. gen. Virol., 73, 3051-3064.

83. Roy P. (1996). - Multiple gene expression in baculovirus system. Third generation vaccines for bluetongue disease and African horse sickness disease. Ann. N.Y. Acad. Sci., 23, 318-332.

84. Roy P., Bishop D.H.L., LeBois H. \& Erasmus B.J. (1994). Long-lasting protection of sheep against bluetongue challenge after vaccination with virus-like particles: evidence for homologous and partial heterologous protection. Vaccine, $12,805-811$.

85. Saegerman C. (2006). - Epidémiosurveillance des événements rares chez les bovins en Belgique. Ann. Méd. vét., $150(S), 4-9$

86. Saegerman C., Berkvens D., Godfroid J. \& Walravens K. (2007). - Bovine brucellosis. In Infectious and Parasitic Disease of Livestock. Lavoisier, Provigny, France, in press. 
87. Saegerman C., Berkvens D., Speybroeck N., Roels S., Vanopdenbosch E. \& Thiry E. (2003). - Amélioration de la détection d'une maladie émergente : exemple de l'encéphalopathie spongiforme bovine. In Épidémiologie des maladies émergentes (special issue). Épidémiol. Santé anim., 44, 61-77.

88. Saegerman C., Claes L., Dewaele A., Desmecht D., Rollin F, Hamoir J., Gustin P., Czaplicki G., Bughin J., Wullepit J., Laureyns J., Roels S., Berkvens D., Vanopdenbosch E. \& Thiry E. (2003). - Differential diagnosis of neurologically expressed disorders in Western European cattle. In Risk analysis of prion diseases in animals (C.I. Lasmézas \& D.B. Adams, eds). Rev. sci. tech. Off. int. Epiz., 22 (1), 83-102.

89. Samal S.K., Elhussein A., Holbrook F.R., Beaty B.J. \& Ramig R.F. (1987). - Mixed infection of Culicoides-variipennis with bluetongue virus serotype 10 and serotype 17 evidence for high-frequency reassortment in the vector. J. gen. Virol., 68, 2319-2329.

90. Samal S.K., Livingstone C.W. Jr, McConnell S. \& Ramig R.F. (1987). - Analysis of mixed infection of sheep with bluetongue serotype 10 and 17: evidence for genetic reassortment in the vertebrate host. J. Virol., 61, 1086-1091.

91. Satta G., Goffredo M., Sanna S., Vento L., Cubeddu G.P. \& Mascherpa E. (2004). - Field disinfestation trials against Culicoides in north-west Sardinia. Vet. ital., 40 (3), 329-335.

92. Savini G., Goffredo M., Monaco F., de Santis P. \& Meiswinkel R. (2003). - Transmission of bluetongue virus in Italy. Vet. Rec., 152, 119.

93. Savini G., Goffredo M., Monaco F., Di Gennaro A., Cafiero M.A., Baldi L., De Santis P., Meiswinkel R. \& Caporale V. (2005). - Bluetongue virus isolations from midges belonging to the Obsoletus complex (Culicoides, Diptera: Ceratopogonidae) in Italy. Vet. Rec., 157, 133-139.

94. Schumacher C.L. (2005). - Available products, not licensed in Europe. European Technology Platform for Animal Health. Working Group 2, Brussels, October 12, 2005. Available at: http://www.ifahsec.org/Europe/EUPlatform/ Minutes/WG2/WEB-C.\%20Schumacher.ppt (accessed on 18 June 2006).

95. Scott J.L., Oberst R.D., Channell M.B. \& Osburn B.I. (1987). - Genome segment reassortment between two serotypes of bluetongue virus in a natural host. J. Virol., $61,2670-2674$.

96. Scott J.L., Osburn B.I. \& Barber T.L. (1982). - Recovery of dual serotypes of bluetongue virus from infected sheep and cattle. Vet. Microbiol., 7 (3), 197-207.

97. Slingenbergh J., Gilbert M., de Balogh K. \& Wint W. (2004). - Ecological sources of zoonotic diseases. In Emerging zoonoses and pathogens of public health concern (L.J. King, ed.). Rev. sci. tech. Off. int. Epiz., 23 (2), 467-484.
98. Standfast H.A., Muller M.J. \& Wilson D.D. (1985). Mortality of Culicoides brevitarsis fed on cattle treated with Ivermectin. In Bluetongue and related Orbiviruses (T.L. Barber \& M.M. Jochim, eds). Alan R. Liss Inc., New York, 519-525.

99. Takamatsu H., Mellor P.S., Mertens P.P.C., Kirkham P.A., Burroughs J.N. \& Parkhouse R.M.E. (2003). - A possible overwintering mechanism for bluetongue virus in the absence of the insect vector. J. gen. Virol., 84, 227-235.

100. Taylor W.P. (1986). - The epidemiology of bluetongue. Rev. sci. tech. Off. int. Epiz., 5 (2), 351-356.

101. Thiry E., De Clercq K., Saegerman C. \& Vermeersch J.P. (2002). - La vaccination contre la fièvre aphteuse : perspectives. Bull. GTV, 14, 117-121.

102. Thiry E., Saegerman C., Guyot H., Bodmer M., Kirten P., Losson B., Rollin F., Czaplicki G., Toussaint J.F,, De Clercq K., Dochy J.M., Dufey J., Gilleman J.L. \& Messeman K. (2006). - Clinical cases of bovine bluetongue in Belgium. Vet. Rec., 159 (10), 327.

103. Toma B. \& Thiry E. (1999). - Qu'est-ce qu'une maladie émergente ? Épidémiol. Santé anim., 44, 1-11.

104. Toussaint J.-F., Sailleau C., Mast J., Houdart Ph., Czaplicki G., Demeestere L., VandenBussche F., Van Dessel W., Goris N., Bréard E., Bounaadja L., Thiry E., Zientara S. \& De Clercq K. (2007). - Bluetongue in Belgium, 2006. Emerg. infect. Dis., 13 (4), 614-616.

105. Townley P., Baker K.P. \& Quinn P.J. (1984). - Preferential landing and engorging sites of Culicoides species on a horse in Ireland. Equine vet. J., 16, 117-120.

106. United States Department of Agriculture (USDA) (2005). Overview of the Mediterranean basin bluetongue disease outbreak, 1998-2004. Center for Emerging Issues, Animal and Plant Health Inspection Service, USDA. Available at: http://www.aphis.usda.gov/vs/ceah/cei/taf/emergingdisea senotice_files/bluetongue_medbasin_ednotice_sep_04_files /bluetongue_med_basin_jan_05_update.htm (accessed on 28 October 2006).

107. Urakawa T., French T.J., Adachi Y., Fukusho A., LeBlois H., Flamand M., Mertens P. \& Roy P. (1994). - Synthesis of recombinant baculoviruses expressing the outer capsid protein VP2 of five BTV serotypes and the induction of neutralizing antibodies to homologous and heterologous BTV serotypes. Virus Res., 31, 149-161.

108. Van Boxstael S., Vereecken K., Huyghebaert A., Noteborn H. \& Saegerman C. (2005). - Development of a system for pro-active identification of food-related emerging risks. In Proc. Tenth Conference on Food Microbiology, University of Liège, 23-24 June, 102-103.

109. Venter G.J., Gerdes G.H., Mellor P.S. \& Paweska J.T. (2004). - Transmission potential of South African Culicoides species for live-attenuated bluetongue virus. Vet. ital., 40 (3), 198203. 
110. Veronesi E., Hamblin C. \& Mellor P.S. (2005). - Live attenuated bluetongue vaccine viruses in Dorset Poll sheep, before and after passage in vector midges (Diptera: Ceratopogonidae). Vaccine, 23, 5509-5516.

111. Verwoerd D.W., Louw H. \& Oellermann R.A. (1970). Characterization of bluetongue virus ribonucleic acid. J. Virol., 5, 10-17.

112. Webster W.R., Gard G.P., St George T.D. \& Kirkland P.D. (1992). - The Australian bluetongue control strategy. In Bluetongue, African horse sickness and related Orbivirus (T.E. Walton \& B.I. Osburn, eds). CRC Press, 843-850.

113. Weiss R.A. \& McMichael A.J. (2004). - Social and environmental risk factors in the emergence of infectious diseases. Nature Med., 10 (12), suppl., 70-76.

114. Wittmann E.J., Mellor P.S. \& Baylis M. (2001). - Using climate data to map the potential distribution of Culicoides imicola (Diptera: Ceratopogonidae) in Europe. Rev. sci. tech. Off. int. Epiz., 20 (3), 731-740.

115. World Organisation for Animal Health (OIE) (2006). Handistatus II. Multiannual animal disease status for bluetongue. Available at: http://www.oie.int/hs2/report.asp (accessed on 28 October 2006).
116. World Organisation for Animal Health (OIE) (2006). Bluetongue detected for the first time in Northern Europe. Press release, 23 August. Available at: http://www.oie.int/ eng/press/en_060823.htm (accessed on 28 October 2006).

117. World Organisation for Animal Health (OIE) (2006). Bluetongue in Northern Europe: an OIE Reference Laboratory makes a breakthrough in identifying the vector causing the disease. Press release, 23 October. Available at: http://www.oie.int/eng/press/en_061023.htm (accessed on 28 October 2006).

118. World Organisation for Animal Health (OIE) (2006). Bluetongue. Chapter 2.2.13. In Terrestrial Animal Health Code, 15th Ed. OIE, Paris. Available at: http://www.oie.int/ eng/normes/mcode/en_chapitre_2.2.13.htm (accessed on 28 October 2006).

119. Zientara S. (2005). - Epidémiosurveillance des maladies à transmission vectorielle. Deux exemples: West Nile et fièvre catarrhale des ovins. In Proceedings of the Symposium of the Epidemiology and Animal Health Association [AESA: Association d'Epidémiologie et de Santé Animale], Faculty of Veterinary Medicine, University of Liège, 12 May, 22-33. 
